\title{
Studi Perbandingan Proses Pengelasan Smaw Pada Lingkungan Darat dan Bawah Air Terhadap Ketahanan Uji Bending Weld Joint Material A36
}

\author{
Safira Dwi Anggraeni, Herman Pratikno, dan Yoyok Setyo Hadiwidodo \\ Jurusan Teknik Kelautan, Fakultas Teknologi Kelautan, Institut Teknologi Sepuluh Nopember (ITS) \\ Jl. Arief Rahman Hakim, Surabaya 60111 Indonesia \\ e-mail: hermanp@oe.its.ac.id
}

\begin{abstract}
Abstrak-Penelitian ini bertujuan untuk mengetahui perbedaan nilai kekuatan uji bending, dan kekerasan pada sambungan weld joint plat baja A36 pada proses pengelasan SMAW di lingkungan darat dan bawah air. Penelitian ini menggunakan Baja A36 dengan variasi lingkungan pengelasan yakni di darat dan di bawah air dengan menggunakan las SMAW dan memakai elektroda E7018 diameter $3,2 \mathrm{~mm}$. Spesimen dilakukan pengujian bending berupa face bend dan root bend, pengujian kekerasan dan foto mikro. Pada pengujian bending pengelasan di darat tidak menghasilkan cacat yang berarti, sedangkan untuk hasil pengujian bending face dan root pada pengelasan bawah air terdapat cacat sepanjang daerah lasan sebesar $38 \mathrm{~mm}$, hal ini tidak dapat diterima karena ukuran cacat lebih besar dari persyaratan yang ada pada ASME Section IX edisi 2015. Pada pengujian kekerasan, nilai kekerasan tertinggi pada pengelasan di darat adalah 200,5 HVN sedangkan nilai kekerasan teritinggi pada pengelasan bawah air adalah 290,2 HVN. Hasil pengujian kekerasan tertinggi pada pengelasan bawah air lebih rendah dari persyaratan AWS D3.6M Underwater Welding Code, sehinga nilai kekerasan memenuhi persyaratan standar. Hasil foto mikro pada pengelasan di darat pada daerah base metal, persentase struktur mikro untuk ferit adalah $75,44 \%$ dan perlit adalah $24,56 \%$. Pada daerah HAZ, persentase struktur mikro untuk ferit adalah $70,11 \%$ dan perlit adalah $28,89 \%$. Pada daerah weld metal, persentase struktur mikro untuk ferit adalah $61,11 \%$ dan perlit adalah $38,89 \%$. Sedangkan untuk hasil foto mikro pada pengelasan di bawah air pada daerah base metal, persentase struktur mikro untuk ferit adalah $74,89 \%$ dan perlit adalah $25,11 \%$. Pada daerah HAZ, persentase struktur mikro untuk martensit adalah 46,11\%, struktur mikro ferit adalah $18,22 \%$ dan struktur mikro perlit adalah $35,67 \%$. Pada daerah weld metal, persentase struktur mikro untuk ferit adalah $\mathbf{4 8 , 9 \%}$ dan struktur mikro perlit adalah $51,1 \%$.
\end{abstract}

Kata Kunci-Kekuatan Bending, Kekuatan Kekerasan, Metalografi, Pengelasan Bawah Air, SMAW.

\section{PENDAHULUAN}

$\mathrm{D}$ ALAM pekerjaan suatu proyek konstruksi, proses pengelasan biasanya digunakan untuk fabrikasi dalam aplikasi engineering,misalnya untuk pesawat terbang, otomotif, dan industri perkapalan [1]. Sekarang ini kebutuhan akan material terutama logam sangatlah penting. Besi dan baja merupakan salah satu kebutuhan yang mendasar untuk suatu konstruksi oleh karena itu kualitas mutu pengelasan harus baik.Untuk mengetahu mutu pengelasan, maka diperlukan uji mekanika antara lain uji bending, uji kekerasan, dan uji metalografi untuk mengetahui struktur mikro hasil pengelasan. Pengujian bending digunakan untuk mengukur kekuatan material akibat pembebanan. Kekuatan bending atau kekuatan lengkung adalah tegangan bending terbesar yang dapat diterima akibat pembebanan luar tanpa mengalami deformasi yang besar atau kegagalan.

Pengelasan merupakan prose s penyambungan antara dua bagian logam atau lebih dengan menggunakan energi panas. Karena proses ini maka di daerah sekitar lasan mengalami siklus termal cepat yang menyebabkan terjadinya perubahanperubahan metalurgi yang rumit, deformasi, dan tegangantegangan termal. Sebagai teknik penyambungan logam pengelasan pada dasarnya merupakan ikatan metalurgi pada sambungan antar logam paduan yang dilaksanakan pada keadaan lumer atau cair maka teknik pengelasan mempunyai keistimewaan dan keunggulan dibandingkan dengan sistem penyambungan logam yang lain seperti keeling.

Cara pengelasan yang paling banyak digunakan pada waktu ini adalah pengelasan dengan busur listrik terlindung [2]. Las busur listrik terlindung atau pengelasan SMAW (Shielded Metal Arc Welding) adalah proses pengelasan yang menggunakan panas untuk mencairkan material dasar dan elektroda. Proses pengelasan SMAW (Shielded Metal Arc Welding) dapat dilakukan di lingkungan darat dan di lingkungan bawah air (underwater wet welding). Pada proses pengelasan SMAW (Shielded Metal Arc Welding) di darat tidak memerlukan perlakuan secara khusus, namun pada saat proses pengelasan SMAW (Shielded Metal Arc Welding) di dalam laut maka kawat elektroda harus dilapisi dengan selotip atau lilin. Pengelasan di bawah air pertama kali dilakukan oleh British Admiralty - Dockyard untuk perbaikan kapal. Sekaran ini pengelasan bawah air banyak dilakukan contohnya unyuk instalasi platform, pengelasan pipeline, dan pengelasan ofshore struktur [3][4]. Kebanyakan pengelasan bawah air menggunakan posisi pengelasan vertikal dan posisi di atas kepala (overhead) dan menjaga agar mutu pengelasan pada 
joint sangat susah karena pengaruh kondisi lingkuran air. [5][6]

\section{METODOLOGI}

Prosedur penyelesaian penelitian yang digunakan terdiri dari beberapa tahapan, yaitu sebagai berikut:

A. Studi Literatur diperoleh dari penelitian sebelumnya, buku, dan jurnal.

Surface Preparation

Persiapan Material Las

Spesimen uji dibuat berbentuk persegi empat dengan ukuran dan tipe sebagai berikut:

Tipe : ASTM A36

Panjang : $300 \mathrm{~mm}$

Lebar : $150 \mathrm{~mm}$

Tebal $: 10 \mathrm{~mm}$

Kampuh : Single V-groove

\section{B. Persiapan Larutan Media Uji}

Digunakan komposisi kimia pengganti air laut sesuai dengan standart ASTM D1141-90, "Standard Spesification for Subtitute Ocean Water” yakni pada salinitas 35\%. [7].

\section{1) Pesiapan Percobaan}

a. Persiapan WPS, dipersiapkan sebagai bkualifikasi tertulis dari prosedur pengelasan yang digunakan.

b. Proses Pengelasan SMAW di Lingkungan Darat

c. Langkah selanjutnya adalah proses pengelasan. Pengelasan kali ini menggunakan las jenis SMAW dengan menggunakan jenis elektroda E-6013.

d. Proses Pengelasan SMAW wet welding di lingkungan air laut salinitas 35\%

e. Dilakukan uji kualitas las dengan menggunakan uji NDT (non destructive test) yaitu ultasonik test.

\section{2) Uji Mekanis}

Sampel uji disiapkan sesuai persyaratan yang tercantum dalam standart pengujian. Berikut yang menjadi acuan dalam persiapan sampel uji:

a. ASME Section IX QW - 462.3 (a) Test Specimen Bends - Face and Root Bends Transverse [8].

b. ASTM E92 Standard Test Method for Vickers Hardness of Metallic Materials. Standart untuk pengujian kekerasan Vickers hasil lasan [9].

c. Uji Metalografi dilakukan sesuai dengan ASTM E3-01 Standard Guide Preparation of Metallographc Specimens [10]. Pengambilan foto struktur mikro dilakukan pada daerah logam lasan (weld metal), batas las, HAZ, dan logam induk.

Selanjutnya dilakukan analisa dan pembahasan mengenai data hasil pengujian tersebut.

Kemudian untuk selanjutnya dapat membuat kesimpulan dan saran.

\section{ANALISA DAN PEMBAHASAN}

\section{A. Hasil Pengujian Kekerasan Vickers}

Pengujian kekerasan dilakukan pada 9 titik meliputi logam dasar (Base Metal) sebanyak 3 titik. HAZ sebanyak 3 titik, dan Weld Metal sebanyak 3 titik. Pengujian dilakukan untuk melihat perbedaan nilai kekerasan antara kondisi pengelasan yang bervariasi. Hasil dari pengujian kekerasan untuk pengelasan SMAW di lingkungan darat dapat dilihat pada tabel 1.

Setalah didapatkan nilai kekerasan untuk pengelasan di darat maka nilai kekerasan ditansformasikan ke dalam grafik pada gambar 3.

Dari grafik pada gambar 3 dapat dilihat bahwa letak kekerasan tertinggi rata - rata terdapat di daerah Base Metal dengan nilai kekerasan tertinggi pada line 3 yaitu 200,5 HVN. Pada derah HAZ, terjadi penurunan nilai kekerasan dari Base Metal ke daerah HAZ dengan nilai kekerasan tertinggi yaitu 160,5 HVN pada line 3. Dan untuk daerah weld metal, nilai kekerasan tidak lebih tinggi dari daerah HAZ kecuali untuk line 1 nilai kekerasan daerah weld metal lebih besar dari nilai kekerasan pada HAZ yaitu sebesar 160,7 HVN.

Untuk hasil dari pengujian kekerasan pada pengelasan SMAW di bawah air dapat dilihat pada tabel 2.

Setalah didapatkan nilai kekerasan untuk pengelasan di bawah air maka nilai kekerasan ditansformasikan ke dalam grafik pada gambar 4 .

Dari grafik hasil uji kekerasan pada gambar 4 dapat dilihat nilai kekerasan tertinggi terdapat di daerah HAZ dengan nilai kekerasan tertinggi pada line 1 yaitu sebesar 290,2 HVN. Sedangkan pada daerah base metal dan weld metal nilai kekerasan tidak lebih tinggi daripada nilai kekeraasan pada daerah HAZ. Pada daerah base metal nilai kekerasan tertinggi terdapat pada line 2 yaitu 205,2 HVN dan pada daerah weld metal nilai kekerasan tertinggi terdapat pada line 3 yaitu 172,1 HVN.

Berdasarkan standart AWS D3.6M nilai kekerasan maksimum hasil pengelasan bawah air untuk HAZ dan weld metal kelas A adalah 325 HVN [11]. Maka untuk hasil uji kekerasan pada pengelasan bawah air sampel uji telah memenuhi standart AWS D3.6M karena nilai kekerasan tertingi dibawah $325 \mathrm{HVN}$.

Dari analisa terhadap nilai kekerasan pada pengelasan di darat dan bawah air menghasilkan kesimpulan bahwa pengelasan SMAW di lingkungan laut lebih keras pada daerah HAZ dibandingkan dengan pengelasan SMAW di darat. Hal ini dapat dilihat pada grafik perbandingan rata - rata nilai kekerasan pada gambar 5 .

Hal ini disebabkan karena pengaruh media pengelasan, air laut dapat mempengaruhi pendinginan yang terjadi setelah dilakukan pengelasan. Nilai kekerasan tertinggi terdapat pada daerah HAZ untuk spesimen hasil pengelasan SMAW di bawah air. Hal ini disebabkan karena pada daerah HAZ 
Tabel 1.

Hasil Uji Kekerasan Pengelasan SMAW di Darat

\begin{tabular}{|c|c|c|c|c|c|c|c|}
\hline \multirow[t]{2}{*}{$\begin{array}{l}\text { Kondisi } \\
\text { Pengelasan }\end{array}$} & \multirow[t]{2}{*}{ Material } & \multirow[t]{2}{*}{$\begin{array}{l}\text { Lokasi } \\
\text { Test }\end{array}$} & \multicolumn{5}{|c|}{$\begin{array}{l}\text { Vickers Hardness Number (HV) } \\
\text { F }=9,808 \mathrm{~N}\end{array}$} \\
\hline & & & No. & $\begin{array}{c}\text { Line } \\
1\end{array}$ & $\begin{array}{c}\text { Line } \\
2\end{array}$ & $\begin{array}{c}\text { Line } \\
3\end{array}$ & $\begin{array}{c}\text { Rata } \\
\text { - }\end{array}$ \\
\hline \multirow{9}{*}{$\begin{array}{l}\text { SMAW di } \\
\text { lingkungan } \\
\text { darat }\end{array}$} & \multirow{9}{*}{$\begin{array}{l}\text { ASTM } \\
\text { A36 }\end{array}$} & \multirow{3}{*}{$\begin{array}{l}\text { Base } \\
\text { Metal }\end{array}$} & 1 & 156,3 & 183,9 & 200,5 & 180,2 \\
\hline & & & 2 & 164,5 & 163 & 188,8 & 172,1 \\
\hline & & & 3 & 151,1 & 163,5 & 178,1 & 164,2 \\
\hline & & \multirow{3}{*}{ HAZ } & 4 & 141 & 140,1 & 154,5 & 145,2 \\
\hline & & & 5 & 143,8 & 149,9 & 156,7 & 150,1 \\
\hline & & & 6 & 135,1 & 146,6 & 160,5 & 147,4 \\
\hline & & \multirow{3}{*}{$\begin{array}{l}\text { Weld } \\
\text { Metal }\end{array}$} & 7 & 160,7 & 147,7 & 134,5 & 147,7 \\
\hline & & & 8 & 135,1 & 144,3 & 137,9 & 139,1 \\
\hline & & & 9 & 129,9 & 142,6 & 151,1 & 141,2 \\
\hline
\end{tabular}

Tabel 2.

\begin{tabular}{|c|c|c|c|c|c|c|c|}
\hline \multirow[t]{2}{*}{$\begin{array}{c}\text { Kondisi } \\
\text { Pengelasan }\end{array}$} & \multirow[t]{2}{*}{ Material } & \multirow[t]{2}{*}{$\begin{array}{l}\text { Lokasi } \\
\text { Test }\end{array}$} & \multicolumn{5}{|c|}{$\begin{array}{l}\text { Vickers Hardness Number (HV) } \\
\text { F = 9,808 N }\end{array}$} \\
\hline & & & No. & $\begin{array}{c}\text { Line } \\
1\end{array}$ & $\begin{array}{c}\text { Line } \\
2\end{array}$ & $\begin{array}{c}\text { Line } \\
3\end{array}$ & $\begin{array}{c}\text { Rata } \\
- \\
\text { Rata }\end{array}$ \\
\hline \multirow{9}{*}{$\begin{array}{l}\text { SMAW di } \\
\text { bawah air }\end{array}$} & \multirow{9}{*}{$\begin{array}{c}\text { ASTM } \\
\text { A36 }\end{array}$} & \multirow{3}{*}{$\begin{array}{l}\text { Base } \\
\text { Metal }\end{array}$} & 1 & 148,7 & 188,5 & 191,9 & 176,4 \\
\hline & & & 2 & 149,7 & 205,2 & 203,6 & 186,2 \\
\hline & & & 3 & 158,1 & 183,4 & 177 & 172,8 \\
\hline & & \multirow{3}{*}{ HAZ } & 4 & 290,2 & 206,6 & 233,2 & 243,3 \\
\hline & & & 5 & 216,8 & 194,1 & 216,8 & 209,2 \\
\hline & & & 6 & 212,2 & 184,8 & 208,8 & 201,9 \\
\hline & & \multirow{3}{*}{$\begin{array}{l}\text { Weld } \\
\text { Metal }\end{array}$} & 7 & 127,8 & 142,1 & 162,4 & 144,1 \\
\hline & & & 8 & 132,5 & 153,1 & 160,1 & 148,6 \\
\hline & & & 9 & 146,9 & 123,6 & 172,1 & 147,5 \\
\hline
\end{tabular}

Hasil Uji Kekerasan Pengelasan SMAW di Bawah Air

Tabel 3.

Hasil dari Kekuatan Tekuk (Root Bend Test) Hasil Pengelasan SMAW di Darat

\begin{tabular}{|c|c|c|c|c|c|}
\hline \multirow[b]{2}{*}{ No. } & \multirow[b]{2}{*}{$\begin{array}{c}\text { Sample } \\
\text { Mark }\end{array}$} & \multirow[b]{2}{*}{ Identification } & \multirow[b]{2}{*}{$\begin{array}{l}\text { Diameter } \\
\text { Mandrel }\end{array}$} & $\begin{array}{c}\text { Test } \\
\text { Result }\end{array}$ & \multirow[b]{2}{*}{ Result } \\
\hline & & & & $\begin{array}{c}\text { Open } \\
\text { Defect } \\
(\mathbf{m m})\end{array}$ & \\
\hline 1 & $\mathrm{~A} 1$ & Root Bend 1 & 32 & 2,23 & Accepted \\
\hline 2 & A2 & Root Bend 2 & 32 & - & Accepted \\
\hline 3 & A3 & Root Bend 3 & 32 & - & Accepted \\
\hline
\end{tabular}

Tabel 4.

Hasil dari Kekuatan Tekuk (Face Bend Test) Hasil Pengelasan SMAW di Darat

\begin{tabular}{cccccc}
\hline \hline No. & $\begin{array}{c}\text { Sample } \\
\text { Mark }\end{array}$ & Identification & $\begin{array}{c}\text { Diameter } \\
\text { Mandrel }\end{array}$ & $\begin{array}{c}\text { Test } \\
\text { Result }\end{array}$ & Result \\
& & & $\begin{array}{c}\text { Open } \\
\text { Defect } \\
\text { (mm) }\end{array}$ & \\
\hline $\mathbf{1}$ & B1 & Face Bend 1 & 32 & 2,30 & Accepted \\
$\mathbf{2}$ & B2 & Face Bend 2 & 32 & - & Accepted \\
$\mathbf{3}$ & B3 & Face Bend 3 & 32 & 2,91 & Accepted \\
\hline \hline
\end{tabular}

temperatur puncaknya merupakan temperatur puncak tertinggi dan memiliki pendinginan pengelasan yang paling cepat karena transfer panas yang cepat. Penurunan kekerasan pada daerah weld metal disebabkan karena adanya hidrogen pada logam cair yang cukup besar. Selain itu, salinitas air laut juga mempengaruhi nilai kekerasan karena salinitas berpengaruh pada pembentukan struktur mikro dari material.

\section{B. Hasil Pengujian Bending}

Hasil dari Kekuatan Tekuk (Root Bend Test) Hasil Pengelasan SMAW di Darat

Pengujian pada spesimen bending ini menggunakan posisi root bend. Tes ini menghasilkan retakan pada permukaan material dengan panjang retak 2,23 mm untuk spesimen A1, sedangkan untuk spesimen A2 dan A3 tidak terdapat retak. Berdasarkan ASME Section IX edisi 2015 cacat ini masih dapat diperbolehkan karena tidak lebih dari 3mm. Sehingga untuk ketiga spesimen A1, A2, dan A3 dinyatakan accepted.

Pengujian pada spesimen bending ini menggunakan posisi face bend. Terdapat retak terbuka atau open crack pada spesimen B1 sebesar 2,30 mm dan spesimen B3 sebesar 2,9 mm, sedangkan untuk spesimen B2 tidak terdapat crack atau none crack. Oleh karena itu ketiga spesimen ini dinyatakan accaptedd karena retak tidak melebihi kriteria yang terdapat di dalam ASME Section IX edisi 2015.

Pengujian pada spesimen bending ini menggunakan posisi root bend. Dari pengujian ini menghasilkan cacat longitudinal crack sepanjang daerah weld metal. Panjang retak untuk spesimen C1 adalah 38,8 mm, spesimen C2 ukuran retaknya $38,2 \mathrm{~mm}$ dan spesimen C3 38,6 mm. Berdasarkan standart kriteria yang ada di ASME Section IX edisi 2015 ketiga material ini dinyatakan rejected karena ukuran cacat melebihi kriteria kelulusan.

Pengujian pada spesimen bending ini menggunakan posisi face bend. Hasil dari pengujian ini menunjukkan bahwa ketiga material uji mengamai open crack sepanjang daerah weld metal yang panjangnya 37,7 mm untuk spesimen D1, 37,6 mm untuk spesimen D2 dan 38,1mm untuk spesimen D3 yang berarti untuk ketiga spesimen ini dinyatakan rejected karena ukuran cacat melebihi kriteria kelulusan yang terdapat di dalam ASME Section IX edisi 2015.

\section{Hasil Pengujian Metalografi \\ 1) Foto Makro}

Dari foto struktur makro di pada gambar 4.17. dapat dilihat bahwa pada pengelasan SMAW di darat terdapat beberapa layer dan tidak terlihat adanya cacat pada daerah weld metal. Sedangkan pada gambar 4.18. untuk pengelasan SMAW di lingkungan laut terdapat beberapa cacat yaitu IP (Incomplete Penetration) pada root dan porosity. Leburan antar layer juga tidak sempurna dengan terlihatnya garis - garis antar layer. Lebar daerah HAZ juga tidak teratur, terlihat dengan adanya overlaping. Hal ini dapat terjadi karena pada saat pengelasan pandangan welder terganggu akibat benda yang dibiaskan 
Tabel 5.

Hasil dari Kekuatan Tekuk (Root Bend Test) Hasil Pengelasan SMAW di Bawah Air

\begin{tabular}{lccccc}
\hline \hline No. & $\begin{array}{c}\text { Sample } \\
\text { Mark }\end{array}$ & Identification & $\begin{array}{c}\text { Diameter } \\
\text { Mandrel }\end{array}$ & $\begin{array}{c}\text { Test } \\
\text { Result }\end{array}$ & Result \\
\cline { 5 - 6 } & & & $\begin{array}{c}\text { Open } \\
\text { Defect } \\
\text { (mm) }\end{array}$ & \\
\hline $\mathbf{1}$ & C1 & Root Bend 1 & 32 & 38,8 & Rejected \\
$\mathbf{2}$ & C2 & Root Bend 2 & 32 & 38,2 & Rejected \\
$\mathbf{3}$ & C3 & Root Bend 3 & 32 & 38,6 & Rejected \\
\hline \hline
\end{tabular}

Tabel 6.

Hasil dari Kekuatan Tekuk (Face Bend Test) Hasil Pengelasan SMAW di Bawah Air

\begin{tabular}{cccccc}
\hline \hline No. & $\begin{array}{c}\text { Sample } \\
\text { Mark }\end{array}$ & Identification & $\begin{array}{c}\text { Diameter } \\
\text { Mandrel }\end{array}$ & $\begin{array}{c}\text { Test } \\
\text { Result }\end{array}$ & Result \\
& & & $\begin{array}{c}\text { Open } \\
\text { Defect } \\
\text { (mm) }\end{array}$ & \\
\hline $\mathbf{1}$ & D1 & Face Bend 1 & 32 & 37,7 & Rejected \\
$\mathbf{2}$ & D2 & Face Bend 2 & 32 & 37,6 & Rejected \\
$\mathbf{3}$ & D3 & Face Bend 3 & 32 & 38,1 & Rejected \\
\hline \hline
\end{tabular}

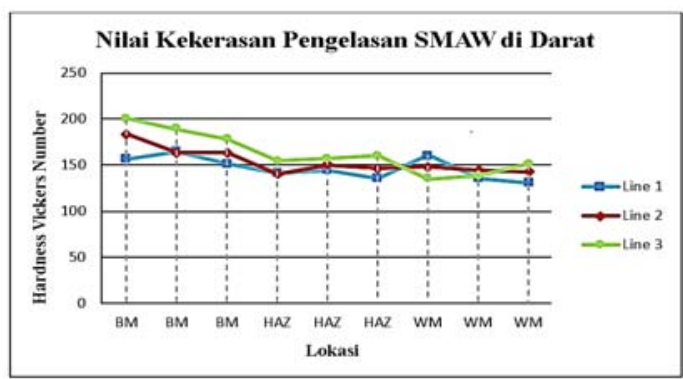

Gambar. 3. Grafik Nilai Kekerasan Pengelasan SMAW di Darat

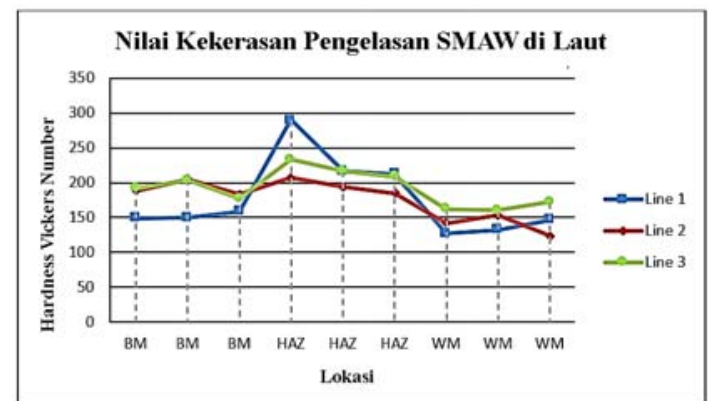

Gambar. 4. Grafik Nilai Kekerasan Pengelasan SMAW di Bawah Air

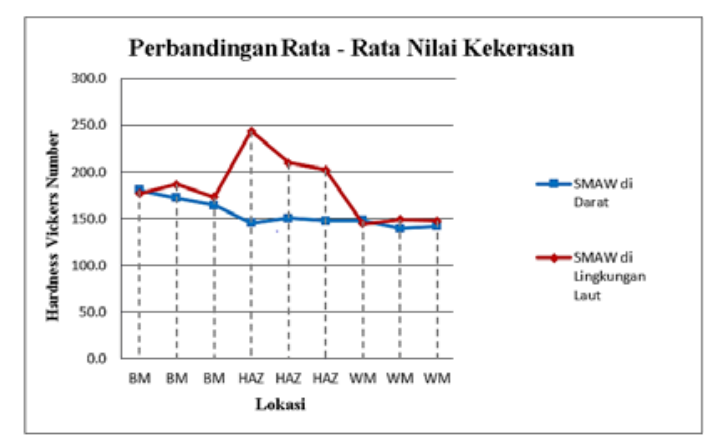

Gambar. 5. Grafik Perbandingan Rata - Rata Nilai Kekerasan

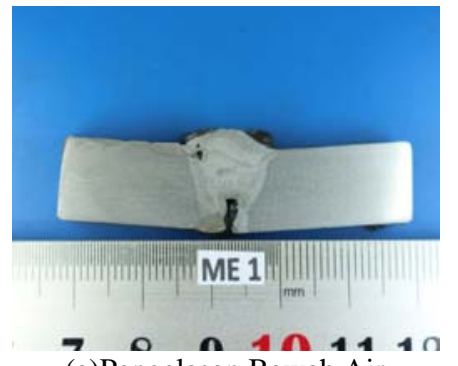

(a)Pengelasan Bawah Air

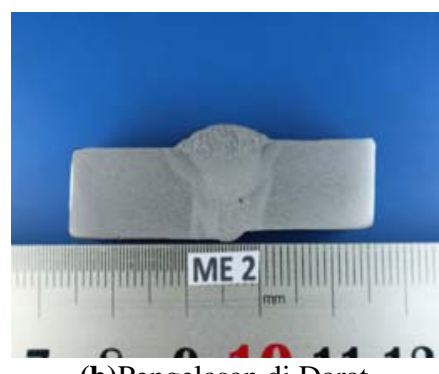

Gambar. 6. Foto Makro

(b)Pengelasan di Darat

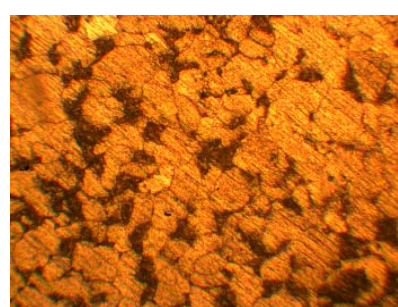

(a) Base Metal

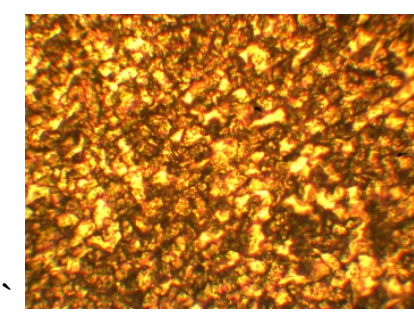

(b) HAZ

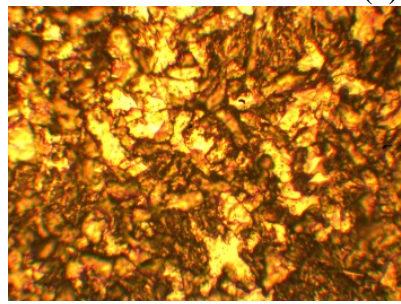

(c) Weld Metal

Gambar. 7. Foto Mikro SMAW di Darat

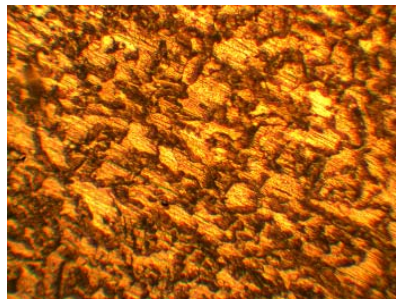

(a) Base Metal

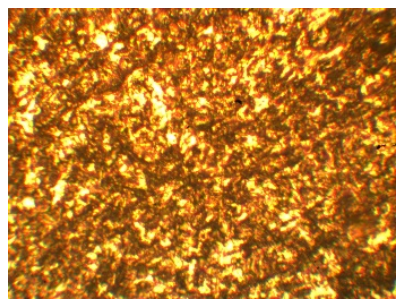

(b) HAZ

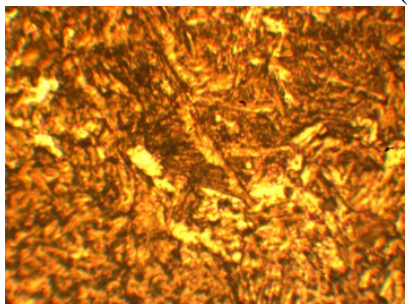

(c) Weld Metal
Gambar. 8. Foto Mikro SMAW di Bawah Air 


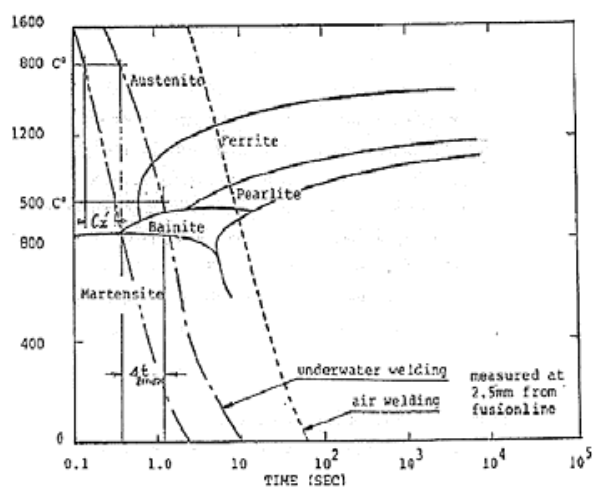

Gambar. 9. Diagram CCT [12]

oleh media air dan juga munculnya gelembung - gelembung gas di air dan pembakaran pelindung flux elektroda yang menyebabkan keruhnya air.

\section{2) Foto Mikro}

Untuk keperluan pengamatan struktur mikro masing-masing spesimen diambil sampel foto struktur mikro dengan pembesaran $(100 \mathrm{X})$ dan $(400 \mathrm{X})$ di tiga titik. Ketiga titik tersebut adalah base metal, HAZ dan Weld Metal.

Dari hasil foto struktut mikro pada gambar 6 pada daerah base metal struktur yang terbentuk adalah ferit dan perlit. Butir ferit berwarna terang dan perlit berwana gelap dengan prosentase butir ferit sebanyak $75,44 \%$ dan perlit sebanyak 24,56 \%. Pada daerah HAZ nampak terlihat jelas adanya perubahan ukuran butir ferit dan perlit yang lebih kecil. Persentase Struktur mikro ferit adalah $70,11 \%$ sedangkan struktur mikro perlit adalah 28,89\%. Pada daerah weld metal struktur mikro didominasi oleh butir-butir ferit yang berwarna terang, sedangkan butir-butir perlit yang berwarna gelap lebih sedikit. Butir perlit yang terdapat pada material cenderung keras sedangkan butir ferit cenderung lunak atau ulet. Persentase Struktur mikro ferit adalah $61,11 \%$ sedangkan struktur mikro perlit adalah 38,89\%.

Dari gambar 7 struktur mikro dengan perbesaran 400X yaitu pada spesimen-spesimen yang di las pada media bawah air tampak pada daerah base metal terdapat kristalisasi antara ferit dan perlit. Daerah base metal tidak terlalu banyak mengalami perubahan struktur, karena pada daerah tersebut tidak terkena pengaruh panas. Butir perlit berwarna gelap yang terdapat pada material. Pada base metal, persentase Struktur mikro ferit adalah 74,89\% sedangkan struktur mikro perlit adalah 25,11\%.

Pada daerah HAZ martensit lebih mudah terbentuk karena ada transformasi ukuran butir dari fasa austenit ke ferit, pada transformasi ini terjadi suatu proses penumbuhan butir yang dipengaruhi oleh waktu. Karena laju pendinginan yang sangat cepat aibat media pengelasan berupa air, maka atom karbon tersebut terperangkap dalam larutan sehingga terbentuk fasa martensit. Terlihat pada daerah HAZ fasa martensit terbentuk pipih seperti jarum. Pada daerah HAZ juga terdapat fasa ferit dan perlit namun presentasinya tidak lebih banyak dari fasa martensit. Fasa martensit ini yang menyebabkan material bersifat getas dan keras. Persentase Struktur mikro pada daerah HAZ yaitu ferit sebesar 18,22\%, perlit sebesar 35,67\%, dan martensit sebesar 46,11\%.

Untuk daerah weld metal didominasi butir-butir perlit yang berwarna gelap, sedangkan butir-butir ferit lebih sedikit (berwarna terang). Butir ferit cenderung lebih halus sedangkan butir perlit lebih kasar. Butir perlit cenderung keras sedangkan butir ferit cenderung lunak atau ulet. Pada weld metal, persentase Struktur mikro ferit adalah 48,9\% sedangkan struktur mikro perlit adalah 51,1\%.

Formasi dari struktur mikro yang terbentuk pada pengelasan di bawah air terutama pada daerah HAZ bergantung pada komposisi kimia yang ada pada base metal dan weld metal, temperatur air dan lama pendinginan.

Pada gambar 9 diagaram CCT (Continuous Cooling Transformation) menunjukkan tahap - tahap transformasi selama pendinginan dari setiap jenis struktur mikro yang berhubungan dengan suhu pendinginan. Pada pengelasan di bawah air dengan suhu air dan laju pendinginan yang cepat akan membentuk fasa martensit pada daerah HAZ. Hal ini dapat terjadi karena pada daerah weld metal terjadi perubahan fasa dari austenit ke ferit dan perlit sedangkan pada daerah HAZ terjadi perubahan fasa austenit ke martensit. Pada perubahan fasa di daerah weld metal, hidrogen berpindah menuju daerah HAZ karena pada daerah weld metal fasa austenit tidak dapat menyerap hidrogen dan hidrogren terlarut dalam fasa ferit. Pada daerah base metal tidak banyak terjadi perubahan fasa karena pada daerah ini kandungan karbon lebih tinggi dari daerah weld metal dan tidak terimbas panas. Pada daerah HAZ perubahan austenit ke martensit terjadi setelah perubahan fasa austenit ke ferit dan perlit di daerah weld metal[13]. Terbentuknya fasa martensit akan menyebabkan terjadinya cacat retak hidrogen karena suhu yang rendah dan laju pendinginan yang cepat dengan media air disekitarnya merupakan faktor utama dalam pembenrukan fasa martensit akibat adanya hidrogen dari dekomposisi air.

\section{KESIMPULAN}

\section{A. Kesimpulan}

Dari hasil penelitian yang dilakukan dalam tugas akhir ini dapat diambil kesimpulan sebagai berikut :

1. Nilai kekerasan di bawah air adalah 290,2 HVN lebih tinggi daripada nilai kekerasan di darat yaitu 200,5 HVN dan hasil pengujian kekerasan tertinggi pada pengelasan bawah air lebih rendah dari persyaratan AWS D3.6M Underwater Welding Code, sehinga nilai kekerasan memenuhi persyaratan standar.

2. Hasil pengujian bending face dan root menunjukkan bahwa pengelasan di darat tidak menghasilkan cacat yang berarti, sedangkan pengujian bending face dan root menunjukkan bahwa pengelasan di bawah air terdapat retak sepanjang daerah lasan, hal ini tidak dapat diterima karena ukuran cacat lebih besar dari persyaratan yang ada pada ASME Section IX edisi 2015.

3. Hasil foto mikro menunjukkan pada pengelasan di darat fasa yang terbentuk pada daerah base metal, HAZ dan 
weld metal adalah ferit dan perlit. Sedangkan pada pengelasan di bawah air struktur mikro yang terbentuk adalah martensit, ferit, dan perlit.

\section{B. Saran}

1. Pengelasan sebaiknya dilakukan pre-heating dan postheating terlebih dahulu untuk menghindari perubahan suhu secara mendadak sehingga pendinginan cepat pada pengelasan bawah air dapat dikurangi.

2. Agar menghasilkan sambungan las yang baik dan memenuhi standar kriteria pengelasan bawah air, perlu menggunakan system las otomatis untuk menghindari faktor kesaalahan manusia (human error) yang cukup berpengaruh pada hasil dan kualitas lasan.

3. Pada dasarnya pengelasan bawah air bersifat darurat dan bukan pengelasan terencana, pada penelitian selanjutnya dapat dilakukan perubahan variasi seperti tingkat kadar garam, tekanan.

\section{DAFTAR PUSTAKA}

[1] Gery , D., Long, H., Maropoulos, P. 2005. "Effects of welding speed, energy input and heat source distribution on temperature variations in butt joint welding”. Journal of Materials Processing Technology. 167 : 393-401.

[2] Wiryosumarto, H., Toshie Okumora. 1996. “Teknologi Pengelasan Logam”. Jakarta: Pradnya Paramita.

[3] J. Labanowski,2011. "Development of underwater welding techniques," Welding International, vol. 25, no. 12, pp. 933 - 937.

[4] K. Verma and H. Garg. 2012. "Underwater welding - Recent trends and future scope". International Journal on Emerging Technologies, vol. 3, no. 2, pp. 115 - 120.

[5] P. J. Keenan, 1993. "Thermal insulation of wet shielded metal arc welds". USA:MIT.

[6] V. R. Santos. 2012. "Development of an oxyrutile electrode for wet welding". Welding Journal, vol. 91, pp. 318-328.

[7] AWS section D1.1. 2002. "Structural Welding Code - Steel". Florida: American Welding Society.

[8] ASME section IX. 2015. "Qualification Standard For Welding, Brazing, And Fusing Procedures; Welders, Brazers, And Welding, Brazing, And Fusing Operators”. New York : The American Society of Mechanical Engineers New York.

[9] ASTM section E92. 2003. "Standard Spesification for Carbon Structural Steel”. Washington: ASTM Publishing.

[10] ASTM section E3-01. 2002. "Standard Guide for Preparation of Metallographc Specimens". Washington: ASTM Publishing.

[11] AWS section D3.6M. 2010. "Underwater Welding Code" . Florida: American Welding Society.

[12] Omajene, Joshua E. et al., 2014., "Fundamental Difficulties Associated With Underwater Wel Welding”. Journal of Engineering Reasearch and Applicatuons 4(6):26-31.

[13] S. Kou. 2003. "Welding Metallurgy”. USA: Wiley Interscience. 